\title{
Sweet's Syndrome as Manifestation of Active Ulcerative Colitis
}

\author{
Mario Bento-Miranda David N. Perdigoto Sofia Mendes Francisco Portela \\ Serviço de Gastrenterologia, Centro Hospitalar e Universitário de Coimbra, Coimbra, Portugal
}

\section{Keywords}

Ulcerative colitis · Inflammatory bowel disease .

Extraintestinal manifestations · Golimumab · Infliximab

\section{A síndrome de Sweet como manifestação extra-intestinal de colite ulcerosa ativa}

\section{Palavras Chave}

Colite ulcerosa · Doença inflamatória intestinal .

Manifestações extra-intestinais · Golimumab · Infliximab

A 63-year-old woman with an extensive ulcerative colitis (UC) diagnosed over a decade ago presented with a history of abrupt onset of fever and erythematous nodular skin lesions, as well as increased bloody diarrhea and osteoarticular pain. She had been treated with mesalazine, azathioprine (suspended due to side effects), and infliximab (IFX). Physical examination showed the presence of erythematous skin lesions (Fig. 1-3). Blood analysis revealed elevated inflammatory markers, low

\section{KARGER}

E-Mail karger@karger.com www.karger.com/pjg
(C) 2019 Sociedade Portuguesa de Gastrenterologia Published by S. Karger AG, Basel

Karcer

Open access

This article is licensed under the Creative Commons AttributionNonCommercial-NoDerivatives 4.0 International License (CC BYNC-ND) (http://www.karger.com/Services/OpenAccessLicense). Usage and distribution for commercial purposes as well as any distribution of modified material requires written permission. circulating IFX levels, and significantly high anti-IFX antibodies. We performed a colonoscopy which evidenced signs compatible with active severe UC (Mayo endoscopic subscore: 3 ). Consequently, the patient was started on systemic corticotherapy.

The skin lesions were biopsied (Fig. 4), allowing to establish the diagnosis of Sweet's syndrome according to the revised criteria: abrupt onset of tender or painful erythematous plaques plus neutrophilic dermal infiltrate without leukocytoclastic vasculitis. Since a predominantly deep inflammatory infiltrate of hypodermis was acknowledged, this case was classified as a subcutaneous variant [1]. The patient also displayed variable features (minor criteria), such as fever and elevated inflammatory markers, which corroborates the diagnosis. Following this finding, we added a corticosteroid topical formulation for the skin lesions. Additionally, IFX was replaced by golimumab. The patient showed progressive improvement of both skin lesions and gastrointestinal symptoms, without relapsing. After discharge, methotrexate was added to the therapeutic plan.

Four months later, the patient was asymptomatic and with normalized inflammatory markers. The patient was

Dr. Mario Bento-Miranda Serviço de Gastrenterologia Centro Hospitalar e Universitário de Coimbra Rua Virgílio Correia ${ }^{\circ} 703^{\circ}$ direito, PT-3000-413 Coimbra (Portugal) E-Mail mariobentomiranda@ hotmail.com 


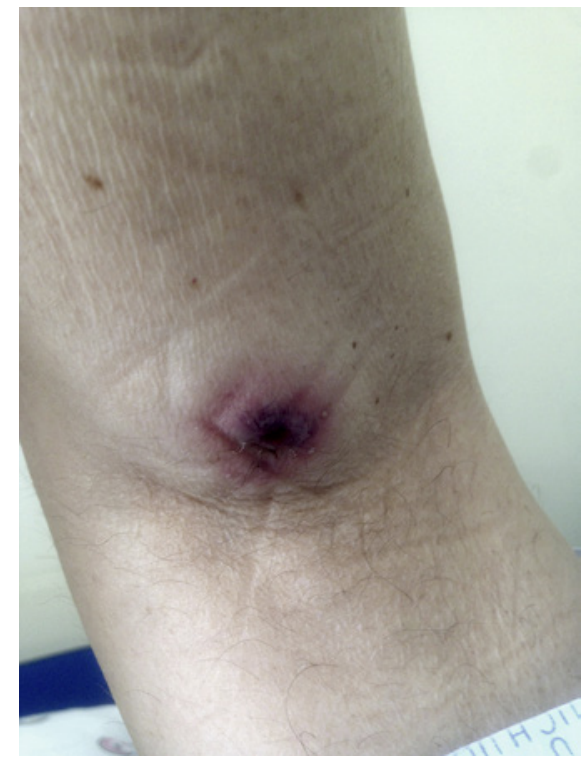

Fig. 1. Painful, infiltrative, and erythematous plaque lesion with purple to reddish center on the posterior aspect of the left leg.

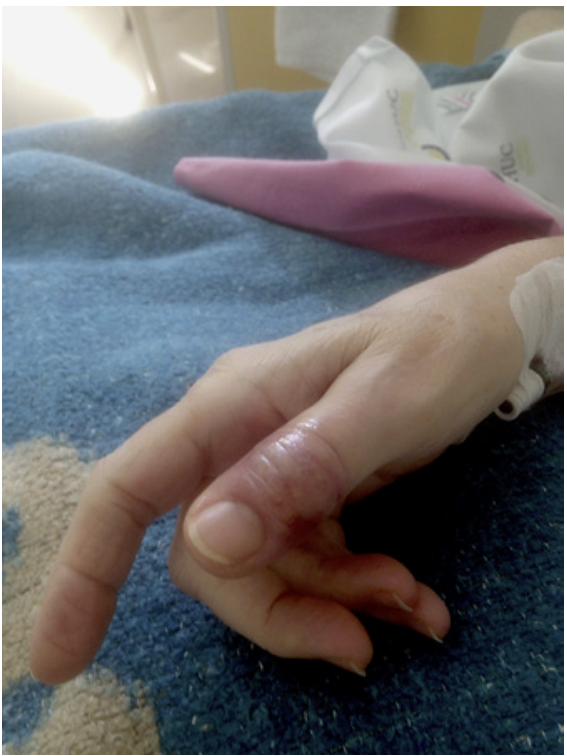

Fig. 2. Nodular, mild erythematous lesion on the posterior aspect of the interphalangeal joint of the right thumb.

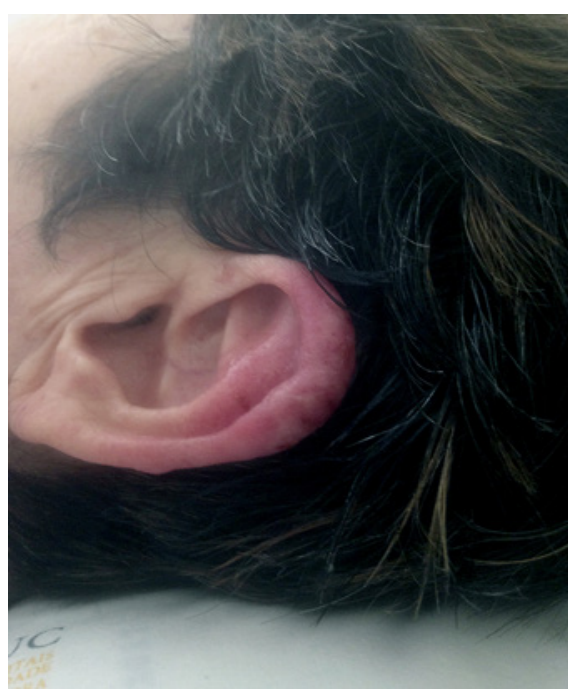

Fig. 3. Violaceous papular rash on the superior peripheral aspect of the left auricle, most prominent in the helix.

kept on a high golimumab dose (100 $\mathrm{mg}$ in a patient with a body weight of $59 \mathrm{~kg}$ ) due to the severity of the flair. We chose the 100-mg dose despite $<80 \mathrm{~kg}$ of body weight due to recent data pointing to lower trough levels in $50-\mathrm{mg}$ non-responders, and methotrexate because the patient presents an increased risk of immunogenicity to the second anti-TNF. The treatment was discussed with the patient, and she was aware that full scientific support was lacking for both decisions [2].

Sweet's syndrome is a rare extraintestinal manifestation of UC. This condition is an acute febrile neutrophilic dermatosis, characterized by a sudden reactive onset of painful erythematous skin papules and nodules that may coalesce into plaques, and is usually accompanied by fever and rising inflammatory markers (such as neutrophilia) [3].

In most cases, it is a neutrophil-mediated idiopathic hypersensitivity reaction. However, it may be associated with various factors, such as malignancies, infection, drugs, vaccination or, as in UC, inflammatory processes. Histologically, it translates as a dense neutrophilic infiltrate in the reticular dermis. One of the features that allows its differentiation from the other types of dermatosis is the absence of signs of leukocytoclastic vasculitis [1].

Treating the underlying condition is usually enough to attenuate or completely heal the cutaneous lesions, in most cases without scarring, although systemic, high-

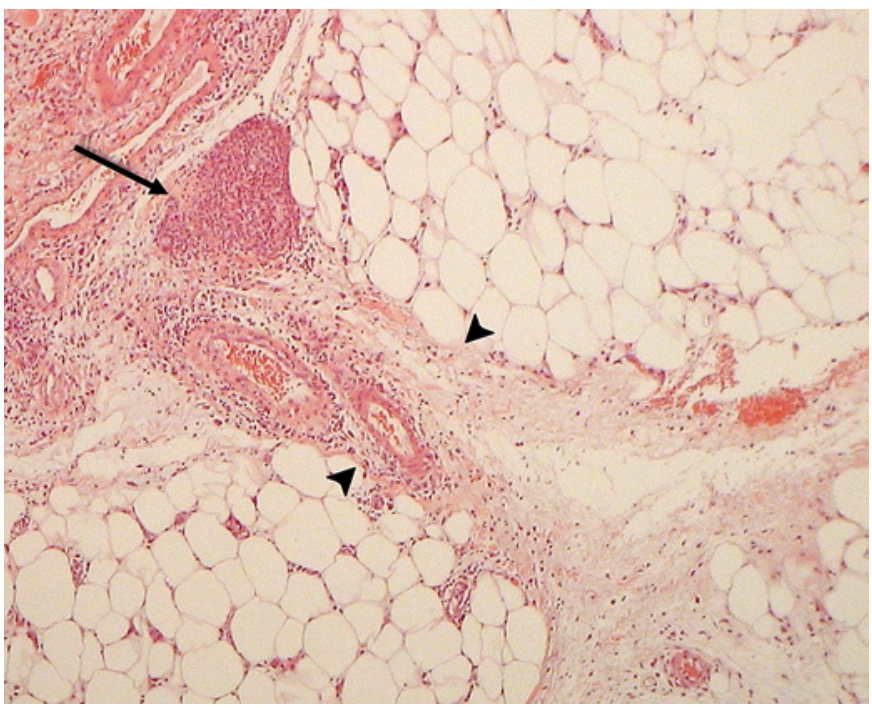

Fig. 4. Skin biopsy of a lesion on the anterior aspect of the right leg (H\&E, 100×). Within the dermis, only a diffuse swallowing and scarce perivascular lymphomononuclear inflammatory infiltrate can be observed. The alterations in this sample are found predominantly throughout the hypodermis, mostly in the septa, as shown in this figure (between arrowheads). They present thickened, edematous, and with a neutrophilic infiltrate that constitute focal nodular aggregates (arrow) which vaguely resemble granuloma. 
dose topic or intralesional corticosteroids may be necessary in more severe presentations. Up to one third of the patients have recurrent lesions [4].

\section{Acknowledgments}

We thank Dr. José C. Cardoso for allowing us to use the figures of the skin biopsy.

\section{Statement of Ethics}

I, the corresponding author, testify on behalf of all the co-authors that the subject mentioned gave her written informed consent to publish this case.

\section{Disclosure Statement}

F. Portela reports receiving lecture fees or serving as a board member from AbbVie, Celgene, Dr. Falk Pharma, Ferring Pharmaceuticals, Janssen Pharmaceuticals, Pfizer, Schering-Plough, and Takeda Pharmaceuticals. M. Bento-Miranda, D.N. Perdigoto, and S. Mendes have no conflicts of interest to declare.

References

1 Nofal A, Abdelmaksoud A, Amer H, Nofal E, Yosef A, Gharib K, et al. Sweet's syndrome: diagnostic criteria revisited. J Dtsch Dermatol Ges. 2017 Nov;15(11):1081-8.

2 Philip G, Cornillie F, Adedokun JO, Melsheimer R, Rutgeerts P, Colombel JF, et al. Early dose optimization of golimumab in nonresponders to induction treatment for ulcerative colitis is effective and supported by pharmacokinetic data. J Crohns Colitis. 2019 Mar;jjz052.
3 Sweet RD. AN ACUTE FEBRILE NEUTROPHILIC DERMATOSIS. Br J Dermatol. 1964 Aug-Sep;76(8-9):349-56.

4 Hindryckx P, Novak G, Costanzo A, Danese S. Disease-related and drug-induced skin manifestations in inflammatory bowel disease. Expert Rev Gastroenterol Hepatol. 2017 Mar;11(3):203-14.
Bento-Miranda/Perdigoto/Mendes/ Portela 